\title{
Assessment of the Rationality of Gender Studies from the Perspective of Bocheński's Concept of Philosophical Superstition
}

\section{Zdzisław Kieliszek $^{1}$ (D)}

Received: 6 May 2021 / Revised: 29 June 2021 / Accepted: 12 July 2021 /

Published online: 28 July 2021

(c) The Author(s) 2021

\begin{abstract}
In recent years, the issue of the determinants of human gender identity has been lively discussed. In such discussions, there are numerous supporters of the belief that a person's gender identity does not depend directly on a given individual's biological endowment with sex, but is the result of various socio-cultural circumstances in which a given person lives. This view began to gain popularity in the scientific community in the late 1960s and early 1970s. It is now considered paradigmatic in the rapidly evolving interdisciplinary study of cultural gender development, which is commonly referred to as gender studies. Representatives of gender studies often present the findings obtained in the course of their research as brilliant and modern. However, when viewed through the concept of philosophical superstition, authored by the Polish logician Józef Maria Bocheński (1902-1995), it can be concluded that the proponents of gender studies significantly exaggerate the intellectual momentum of their conclusions and postulates. Furthermore, one can even say that according to Bocheński's concept of philosophical superstition, gender studies is a discipline which only creates a semblance of rationality (truth). This is because gender studies fail all six criteria which, as Bocheński maintains, distinguish beliefs, views, and theories which are manifestly irrational from those which are not philosophical superstitions. The article consists of three parts. In the first part, Bocheński's concept of philosophical superstition is discussed and, in particular, the criteria are outlined which, in Bocheński's opinion, allow one to identify philosophically superstitious thinking. This section also provides examples of philosophically superstitious beliefs, views and theories that fall under each of the criteria. In the second part, gender studies are characterized in terms of the basic assumptions adopted within this trend, as well as its theses and postulates. The third part of the article is devoted to the assessment of gender studies with the use of criteria which, according to Bocheński, make it possible to distinguish theories, beliefs and views without the hallmarks of rationality from those that are not philosophically superstitious.
\end{abstract}

Extended author information available on the last page of the article 
Keywords Józef Maria Bocheński · Philosophical superstition · Criteria of irrationality (falsehood) of theories, beliefs, and views · Gender identity · Cultural gender - Gender studies - Gender studies critique

\section{Introduction}

One of the more discussed issues in recent years has been the determinants of human gender identity. In such discussions, there are numerous supporters of the belief that a person's gender identity does not depend directly on the given individual's biological endowment with sex, but is the result of various socio-cultural circumstances in which they live. This belief has become so popular that, ever since the late 1960s and early 1970s, interdisciplinary studies on the development of gender have been growing rapidly. These studies are referred to as gender studies. Proponents of gender studies consistently rate their achievements as brilliant, ground-breaking and modern (see, for example, Baer M., 2004; Sultana and Lazim, 2011; Graff A., 2013; Woodward and Woodward, 2015; Chmura-Rutkowska et al., 2016; Górecki, 2017).

On the other hand, critics of gender studies question their scientific status and warn against the disastrous consequences for the social fabric should the practical demands that are made within the framework of this ideological trend be implemented in the future. One criticism raised is that researchers representing gender studies arbitrarily ignore the biological conditions (i.e. sex) of one's way of experiencing their own sexuality and related matters (in particular, marital relationships and parenthood) and another criticism is that the realisation of such a vision of gender will inevitably lead to the destruction of matrimonial and family ties. In the field of gender studies critique, the flagship character is undoubtedly German publicist and sociologist Gabriele Kuby (see i.a. Kuby, 2007, 2013). She is, by far, not the only challenger of gender studies (as there is no shortage of them) and although criticism of gender studies is levelled from various worldview positions, what is clearly noticeable is that among the voices challenging the achievements of gender studies, those associated with the Catholic intellectual tradition are dominant (see, for example, Jucewicz and Machinek, 2009; Pawłowicz, 2012; Kieliszek, 2014a, b; Niewińska, 2014; Zalewska, 2014; Podzielny, 2016; Czupryński, 2019).

It must be acknowledged that the dispute between representatives of gender studies and their opponents is often marked by excessive emotionality. This means that it is not uncommon for both sides to level almost hysterical accusations against each other. Thus, for example, proponents of gender studies directly equate any criticism of gender studies' achievements with homophobia, hate speech or ignorance (such is the perception of gender studies critiqued by e.g. Duda, 2016; Śmieja, 2017). In turn, the opponents of gender studies in a sharp (even compulsive) tone define this trend of thought as madness, degeneration, etc., which strikes at the foundations of social order (for the presentation of positions from which gender studies are usually criticized, see e.g. Rogowski, 2013; Rogowski, 2015). Consequently, it is difficult to resist the impression that both sides of the dispute over the determinants of human gender identity have long been conducting a kind of crusade against each other, which strongly polarizes both public opinion and the world of science. Such 
an attitude is certainly not conducive to a material discussion of the rational value which the achievements developed in the framework represent.

In view of the excessive emotional fervour which permeates discussions between supporters and opponents of gender studies, I propose to criticize the achievements of this trend of thought relative to the concept of philosophical superstition, authored by Józef Maria Bocheński (1902-1995), ${ }^{1}$ a Polish philosopher, logician, a Dominican friar, and, among other academic positions, the rector of the University of Fribourg. Adopting such a point of view, I think, will allow us to look at gender studies in an intellectually "cold" way, i.e. with an appropriate scientific detachment. Certainly, in the face of a heightened and overly emotional world-view dispute over gender identity, an intellectually "cool" view of gender studies is needed in order to assess the rational integrity of their achievements (cf. Šimo, 2019, pp. 72).

The above-mentioned intention will be achieved in the following steps. First, the concept and examples of philosophical superstition will be presented in Bocheński's view, with particular attention devoted to the criteria he proposed to distinguish beliefs, views and theories that are overtly irrational from those that are not philosophically superstitious. Next, gender studies will be characterized in terms of the basic assumptions adopted within this trend, as well as its theses and postulates. Subsequently, the achievements of gender studies will be assessed from the point of view of Bocheński's concept of philosophical superstition.

\section{Bocheński's Understanding and Examples of "Philosophical Superstition"}

In the literature of the subject, there are two basic concepts of "superstition".

First, "superstition" means convictions (views, beliefs, etc.) and related practices that involve magically appealing to supernatural powers to bring misfortune to someone or to protect one from such misfortune. It is worth noting that such an understanding is in line with the etymology of the Polish term for "superstition" used by Bocheński - zabobon, since this word is derived from bobonienie, an onomatopoeia for slurred and muttered utterances of various spells by fortune-tellers or sorcerers during their rituals. The first meaning of "superstition" is also exemplified by beliefs and practices related to the so-called unlucky number thirteen, black cats, broken mirrors, lucky horseshoes and four-leaf clovers, knocking on wood, crossing one's fingers for luck, or grabbing a button when you see a chimney sweep nearby.

\footnotetext{
1 Bocheński has published about 60 books and several hundred articles on philosophy and the history of philosophy, especially logic and the history of logic. The most important works by Bocheński are: 1) Europäische Philosophie der Gegenwart (Bern 1947); 2) Formale Logik (Freiburg im Breisgau / München 1956); 3) Handbuch des Weltkommunismus (Freiburg im Breisgau / München 1958, in collaboration with Gerhart Niemeyer); 4) Die zeitgenössischen Denkmethoden (Bern 1954); 5) The Logic of Religion (New York 1965); 6) Was ist Autorität? Einführung in die Logik der Autorität (Freiburg im Breisgau 1974). For a detailed list of Bocheński 's bibliography, see e.g. https://pbw.org.pl/przemysl-2.55/ jozef-innocenty-maria-bochenski-1902-1995-bibliografia-podmiotowo-przedmiotowa,12276 [2021-0629].
} 
The second meaning of "superstition" refers to beliefs, views, theories, etc., which are regarded by their followers as true, even though they are manifestly false. It is not necessary for enthusiasts of such beliefs, views, theories, etc. to invoke the influence of supernatural forces - although they may do so. A clear example of superstitious thinking in the second sense of the word are the theories currently preached by so-called flat-earthers or the pseudoscientific (from today's point of view, of course) 19th-century theory that frequent handwashing did not protect people from infectious diseases.

The two basic meanings of "superstition" mentioned above are not disjointed but intersecting. This means that there are views (convictions, beliefs, etc.) that fall under both understandings of "superstition" (see Hummel, 1997; Nisbet, 1998; Vorgrimler, 2005; Kołakowski, 2009; Słownik języka polskiego PWN, 2021).

The concept of philosophical superstition, which Bocheński presents in the treatise One hundred superstitions. A short philosophical dictionary of superstition, belongs to the second of the above-mentioned senses of "superstition". It was edited in 1986 by the Literary Institute of Paris ("Kultura") and saw its first publication one year later. The book is written in a satirical tone and its reader is regaled at every turn with humour or irony and, as a result, it may seem at first glance that Bocheński approaches the issue of superstition lightly. But the playfulness of Bocheński's approach to "superstition" is only a pretence. In fact, he treats the concept of superstition and its designations with absolute seriousness. With careful reading, it turns out that the philosopher presents the criteria by which superstition can be precisely distinguished from what it is not (Jacko, 2013, pp. 135).

According to Bocheński, superstition is any such conviction (belief, view, theory) which is obviously highly irrational, yet is considered by its followers to be absolutely true (Bocheński, 1994, pp. 10). Bocheński gives just over a hundred examples of such superstitious thinking. According to him, superstitions include: astrology, idolatry, democracy, dialectics, economism, humanism, idealism, communism, materialism, nationalism, numerology, psychoanalysis, spiritualism, tolerance and totalitarianism. Although some of the above examples of superstition (e.g. astrology or numerology) have nothing to do with philosophy, even if it is understood very broadly, the Polish logician stresses that the ideas of philosophers are at the root of every superstitious thought. For this reason, Bocheński dubs all One hundred superstitions mentioned in the book, as well as all - in his opinion - irrational convictions, theories or beliefs as "philosophical superstitions" (Bocheński, 1994, pp. 10-11).

According to him, there are six basic criteria for identifying philosophically superstitious thinking.

First, any theories that contain or consistently lead to a contradiction are philosophically superstitious. Typically, the discovery of this inner contradiction also calls for hidden assumptions to be revealed or for necessary consequences of the belief to be shown. Due to their internal contradiction, philosophical superstitions - according to Bocheński - are, for example, the recognition of democracy as the best system of government, or the adoption of philosophical relativism. In the case of democracy, Bocheński notes that even if we observe that this system of government has worked well in a country, it does not lead to the conclusion 
that it would work in another country just as perfectly. According to Bocheński, social reality is too complex for given solutions, which have already worked in one democratic state, to be easily applied to another country that has not yet been democratic (Bocheński, 1994, pp. 29-32). Relativism, in turn, is self-contradictory (an observation which, notably, has been made by Aristitole already). If we assume that "relativism" amounts to the assertion that truth is relative, and if we take account of the hidden premise of that assertion, i.e. that the assertion itself is absolutely true, it is not difficult to see that the phrase "truth is relative" contradicts itself (Bocheński, 1994, pp. 109-110).

Second, superstition is any belief that denies direct experience. In order to demonstrate that a belief is in conflict with direct experience, it is sufficient to refer to the obviousness of certain observations. Therefore, according to Bocheński, faith in activism or materialism, for example, is philosophically superstitious. Proponents of activism believe that human life has value (meaning) only when a person acts, and constantly, consciously strives to achieve something. They condemn any inaction or contemplation, considering them completely useless. However, as Bocheński argues, it is easy to point out numerous human experiences when a person does not consciously pursue a goal and does nothing at all, yet their life does not lose its significance and, even more so, it is then that it acquires its most intense meaning. It is thus, for example, when lazily enjoying the warmth of the sun while lying on the beach, after just bathing in invigoratingly cool seawater (Bocheński, 1994, pp. 15-16). The proponents of materialism, in Bocheński's view, fall into superstitious thinking because they ignore the obvious fact that human consciousness (psyche, soul) cannot be reduced to a phenomenon of material nature alone (Bocheński, 1994, pp. 79-80).

Third, if a theory flies in the face of common sense, then it is also superstitious. This is most often the case where, without sufficient arguments, strongly justified knowledge is rejected. According to Bocheński, some of the most obvious examples of superstitious beliefs that fall under this criterion are all stripes of anarchist theories and the belief in economism. Bocheński notes that the proponents of anarchism believe anarchy to be not only an achievable social system, but even the most desirable one. Anarchists thus ignore the historical experience thus far, on the basis of which, according to Bocheński, it must be concluded that each introduction of anarchic solutions in a given society, instead of prosperity, peace, etc. always brought to its members a great deal of injustice, terror, murder, etc., until finally the society in question was plunged into complete collapse (Bocheński, 1994, pp. 17). In turn, the believers in economism maintain that meeting people's material needs (food, housing, clothes, etc.) is enough to make them happy. Bocheński claims that faith in economism is a philosophical superstition because it rejects the observations on the basis of which it is easy to conclude that even satisfying material needs to excess does not guarantee universal happiness at all. He points out that even in rich, modern societies many people are still unhappy, suffering, etc., even as they possess significant personal wealth. (Bocheński, 1994, pp. 41-42).

Fourth, if the proponents of a view consider it to be duly justified and, in fact, it is not, because the arguments they present are insufficient and much stronger 
counter-arguments can be pointed out, then their thinking is philosophically superstitious. According to Bocheński, some currents of behaviourism and humanism are clear examples of illegitimately justified beliefs. In the case of some trends of behaviourism, he opines that, contrary to a much stronger argument for the existence of mental phenomena (soul), they assume, in an improperly justified manner, i.e. on the basis of much weaker justifications, that mental phenomena (soul) do not exist (Bocheński, 1994, pp. 27-28). A similar issue, according to Bocheński, is found with humanism, if it is understood as the conviction of the essential superiority of man over other elements of the natural world, especially animals. According to him, the arguments used by humanism's supporters (e.g. human use of speech, human reason, creation of technology and culture, experiencing the fear of death), which are to justify the uniqueness of human beings in the natural world, are not absolutely persuasive. In the light of current knowledge, it is recognised that animals also, although to a lesser degree, possess many abilities which are attributed only to man by the representatives of humanism. Moreover, Bocheński notes that, contrary to the beliefs of the followers of humanism, there are many reasons which strongly argue that there is no significant difference between man and higher animals (Bocheński, 1994, pp. 54-57).

Fifth, it is a superstition to regard a given belief as certain. In order to show that in a particular case we are dealing with a superstition, it should be demonstrated that the conviction in question has not been confirmed to such an extent that it can be regarded as irrefutable. According to Bocheński, faith in astrology or historiosophy are fallaciously certain in this particular sense. Enthusiasts of astrology are convinced that the arrangement of celestial bodies which occurs at the time of birth of an individual irrevocably determines their fate. In turn, belief in historiosophy rests on a certainty that it is possible to predict, in the long term, the path of historical events. However, according to Bocheński, both the faith in astrology and in historiosophy are unfounded, since in both cases we do not have data (facts) that would confirm astrological or historiosophical predictions. This means that the predictions of astrologers and historiosophers have not been confirmed to such an extent as to be considered certain. Moreover, strong arguments can be brought that both astrology and historiosophy are merely fairy tales (Bocheński, 1994, pp. 22-24, 53-54).

Sixth, philosophically superstitious thinking confuses the meaning and scope of the terms used. According to Bocheński, this is mainly the case in so-called gibberish, which involves the belief that, with the help of completely incomprehensible expressions (e.g. "abracadabra", "hocus-pocus") or words that are understandable but completely alien to a particular audience (this is especially done by abusing phrases that give the impression of scholarship, e.g. "dialogue", in order to bolster persuasiveness), it is possible to communicate information about reality (Bocheński, 1994, pp. 28-29). Similarly, it is a philosophical superstition to give a meaning to some term which is different from the meaning of that term in the language in which the belief is expressed. This is the case, according to Bocheński, for example in the case of "altruism", if this concept is taken in the sense given to it by the French Enlightenment philosopher Auguste Comte (Bocheński, 1994, pp. 16). It is also superstitious to use vague and ambiguous terms, such as "authority" (Bocheński, 1994, pp. 24-26) or "idolatry” (Bocheński, 1994, pp. 26-27). 
It should be made clear here that, according to Bocheński, each of the above six criteria is sufficient for a view to be regarded as philosophically superstitious. This means that there is no need for them to be met all at once. It is enough that a given view falls under only one of the criteria indicated and it must be regarded as a philosophical superstition (Jacko, 2013, pp. 141-145; Šimo, 2019, pp. 72-74).

\section{Characteristics of Gender Studies - Basic Assumptions, Theses and Postulates}

Gender studies challenge analytical categories which before the advent of this trend were considered obvious and their content fixed once and for all. Those categories include concepts such as masculinity, femininity, gender identity, kinship and family. The challengers are, among others: David Schneider, Jane Collier, Michelle Z. Rosaldo, and Sylvia J. Yanagisako, who laid conceptual foundations for the work of subsequent researchers of similar outlook. Michel Foucault's work History of Sexuality (vol. 1-3, 1976-1984) should also be considered "foundational" for gender studies. In various related fields, studies in socio-cultural identity have been (or are still being) conducted by Henrietta Moore, Signe Howell, Marit Melhuus, Frances Pine, Harriet Whitehead, Floya Anthias, Nira Yuval-Davis, Pnina Werbner, Jennifer Schirmer, Victoria A. Goddard, Anne Allison, Thomas Chivens, Melisa LlewelynDavis, Edward Said, Talal Asad, Homa Hoodfar, Subhadra M. Channa, Suzanne A. Brenner, Carole S. Vance, Emily Martin, Sandra Lee Bartky, Judith Okely, Michele Rivkin-Fish, Annick Prieur, Sofka Zinovieff and Eduardo pp. Archetti, among others. Polish researchers obviously have also contributed to the field of gender studies (whom I enumerate separately on account of my Polish nationality), including Maria Janion, Joanna Senyszyn, Agnieszka Graff, Elżbieta Pakszys, Inga Iwasiów, Agata Chełstowska, Aleksandra Sygnowska, Jacek Kochanowski, Marzena Adamiak, Beata Bielska, Ewa Bińczyk and Aleksandra Derra.

The basic premise of gender studies is that the research approach to reality should distinguish between two perspectives: subjective and objective. The subjective perspective looks at the world through "lenses" of the researcher's own culture (i.e. its specific language, established thought patterns, etc.). On the other hand, the objective perspective attempts to reject such "lenses" because their use seems to distort the results achieved, i.e. it "pollutes" them with concepts, schemas, etc., which, though appropriate for a given culture, may be completely alien to another. An objective perspective is therefore intended to describe, analyse and explain reality in a culturally neutral way. According to the terminology introduced in 1954 by the American linguist Kenneth Pike, the culturally subjective approach is referred to as emic and the approach aiming at cultural neutrality as etic (see Morris et al., 1999, pp. 781-784).

Gender studies cast into doubt whether a culturally neutral perspective is possible in humanities and social reality research. For example, according to D. Schneider, the concept of the family, thus far considered fixed in its sense, as well as independent of place and time, appears to be specific only to Western culture (see Hryciuk and Kościańska, 2007, pp. 9). S.J. Yanagisako and J.F. Collier, in turn, argue that 
there are no biological or material facts which have objectively describable cultural significance, can be analysed and can explain societal consequences. This means that in gender studies that which is related to the description of human biology and its functioning, etc. (e.g. sexual intercourse, pregnancy and childbirth) is treated only as a kind of metaphor, which is expressed using very particular "lenses", specific only to a particular culture. When using other "lenses", the metaphor will be different, which amounts to the recognition that there is no human-independent reality which would necessarily condition, for example, the nature and structure of interpersonal relationships (see Yanagisako and Collier, 2007, pp. 44).

According to representatives of gender studies (e.g. S.J. Yanagisako, J.F. Collier, M.Z. Rosaldo, A. Allison, S. Lee Bartky) the "gain" from realizing that all humanistic and social phenomena - in particular the family, as well as the categories of masculinity and femininity - are merely ideological constructs, specific only to this and no other culture, is the ability to precisely grasp the complexity of meanings of certain concepts in a given conceptual ecology, while avoiding the danger of arbitrary "contamination" by different meanings, which those concepts have in other, distinct cultures (see Collier et al., 2007; Allison, 2007; Bartky, 2007). Indeed, gender studies recognise the existence of biological differences between the sexes, but at the same time, they deny that these differences produce any effects that could be seen as identical in all cultures (see Whitehead, 2007). This means that gender categories and related phenomena (e.g. motherhood, fatherhood, marriage, being a wife, being a husband, and family) are considered by representatives of gender studies (e.g. S. Lee Bartky) to be appropriate only for a particular culture that shapes relationships between people in ways specific to itself (see Bartky, 2007, pp. 52).

Gender studies stress that any socio-cultural model of gender identity should be regarded as a kind of corset that limits and rigidly structures life, psyche as well as self-expression and human relationships with others. On the other hand, it is generally not even taken into account that a particular model of gender identity may also, for representatives of certain cultures, be an impulse that stimulates them to develop, to form bonds with other people, etc., according to the patterns specific to the particular social environment (see e.g. Yanagisako and Collier, 2007, pp. 37). According to representatives of gender studies, it is particularly harmful to distinguish between the spheres of domestic and public life in different cultures, as well as to rigidly model the desirable roles that women and men have to play in each of these spheres. In this way, people are deprived of their right to decide their own lives and fates completely freely (see, for example, Goddard, 2007; Llewelyn-Davies, 2007; Hoodfar, 2007; Channa, 2007; Brenner, 2007; Okley, 2007).

Gender studies also put forward postulates that can be divided into two prongs: research-theoretical and socio-practical.

The first includes: (1) a cultural analysis of the meanings of gender-related categories, which aims to reveal how the categories are understood and how they are implemented by people in a particular culture; (2) creating conceptual models of gender differences specific to a given ideological tradition, with the aim of enabling a study of specific situations, i.e. examining the quality of life of the persons or groups concerned; (3) historical analysis of categories related to sexuality in order to study their development and changes over time, including the discovery of the 
causes and consequences of perceived changes (see e.g. Yanagisako and Collier, 2007, pp. 44-52).

Among the socio-practical postulates, the following come to the fore: (1) a permanent remodelling (through mass media, opinion-forming entities, and positive law) of individual cultures in such a way that they become gender-neutral, i.e. not assigning specific social roles to individuals on the basis of their gender; (2) absolute equality between the obligations and rights of women and men; (3) deconstruction of the division of human life into the domestic and public spheres; 4) enabling all people to have a completely arbitrary choice as to what tasks - so far usually attributed in particular cultures to either women or men - and in what configurations they will perform in life (cf. Kieliszek, 2014b, pp. 167-172).

It is also worth mentioning that in the texts of the representatives of gender studies there are numerous emotionally coloured calls for these postulates, particularly those of a socio-practical stripe, to be realised as soon as possible. For example, pp. Werbner notes that, despite the undoubted successes of various feminist organisations and movements in the fight for women's equality, efforts are still needed to "eliminate" forms of discrimination against people on the basis of their biological sex, which exist in particular societies (Werbner, 2007, pp. 116). C.S. Vance, the author of many articles on human sexuality, speaks outright about a "war of ideas". One side of this confrontation are the proponents - the author herself included - of the understanding of gender and sexual behaviour as socio-cultural concepts, the other - researchers regarding gender and sexual behaviours as determined by biological human endowment (Vance, 2007, p.29). Another representative of gender studies, E. Martin, calls for liberation from a so-called "male perspective" in analyses of problems concerned with human reproduction. According to her, the language customarily used in describing these problems always portrays the male as the active party, while the female is portrayed as passive. This completely distorts the image of factual processes happening during conception. E. Martin remarks, for instance, that ascribing activity to spermatozoa while considering the ovum passive is far from the truth, since the egg is just as, if not more, active in the process of fertilization. She, therefore, postulates that the "male perspective" on reproduction should be abandoned, in favour of a more adequate view which would appreciate the "female role" in the creation of new human life (Martin, 2007).

\section{The Philosophical Superstition of Gender Studies}

Let us now assess gender studies in the light of Bocheński's "philosophical superstition" and each of his criteria for identifying it.

First, gender studies do bear the characteristics of a framework marred by an internal fracture. On the one hand, the field negates the existence of any such dimension of material reality which would have any cultural significance or social consequences for the development of gender identity. On the other hand, however, the development of human gender identity, situated in gender studies only within the realm of cultural meanings and senses, is explained based on the description and analysis of phenomena which belong to that material reality. 
Second, the fundamental claims made within gender studies stand in clear contradiction to direct experience. In this perspective, the human is regarded as a subject whose physicality plays no (or no significant) role in their gender functioning. The representatives of gender studies see gender identity as influenced not primarily by biological physicality (sex), but by the sphere of cultural meanings and senses (gender), i.e. the broadly understood realm of spirit. Meanwhile, a cursory look at human nutrition will convince us that a human being is not only a spirit sustained by ideas alone, but primarily a being integrated in material, physical and biological, reality. In other words, if, in order to survive, a human needs to regularly nourish their organism with sufficient amounts of material food, it is all the more obvious that biological factors must also play a significant (key) role in forming higher aspects of human existence, gender aspects included. This means that in the light of direct experience - exemplified by something as simple as human nutrition, which shows on the most basic level (that of vital functions, survival) the integral connection of human existence with physical, biological reality - it is manifestly irrational to hold to the conviction of gender studies' adherents that human gender identity is completely independent from human physicality.

Third, it flies in the face of common sense to maintain, as the gender studies paradigm does, that there are no social functions and roles appropriate exclusively to biological females and males, as those functions and roles are always culturally conditioned. Although in specific cultures - as the representatives of gender studies correctly note - biological males' and females' functions and roles connected, for example, with parenting, housework, or involvement in public affairs are variously distributed, nevertheless, under normal circumstances, it is the biological females who give birth and biological males who impregnate them. On this basis alone, one can discard the thesis of gender studies that there are no functions and roles ascribed only to a given sex.

Fourth, it is claimed in gender studies that individual cultures propose entirely different models of womanhood and manhood. This claim has become paradigmatic for this school of thought and within it is considered unassailable, i.e. absolutely certain, verified once and for all, unfalsifiable, etc. However, intellectual honesty (scientific scrupulousness) would require a constant re-examination - and by the representatives of gender studies themselves, who do not do this as a principle, as far as one can tell, rather than by their critics - whether this approach leads to overlooking certain "cultural mechanisms" which in all, or at least some, cultures and societies identically circumscribe womanhood and manhood. It is perhaps also possible to show that the socio-cultural patterns and phenomena which are interpreted as different within gender studies are, in their essence, identical. Or, it could be demonstrated that the differences found in particular cultural models of womanhood and manhood are only marginal in nature and not - as claimed by the adherents of gender studies - fundamental. A mere pointing out of these doubts and possibilities makes the theses and postulates raised within gender studies appear as insufficiently justified for the time being.

Fifth, the structure of gender studies inherently includes certain postulative ideas which demand a wholesale remodelling of the socio-cultural reality external to the individual, in order to secure a life for future generations which is incomparably superior to the present one in civilizational terms. However, these postulates are built upon 
hypotheses whose current certainty seems insufficient to construct expectations which are so monumental and far-reaching in terms of their potential repercussions that should they be universally adopted and allowed to transform the socio-cultural reality. In other words, there is too little proven in gender studies to allow positing such far-reaching socio-practical postulates. Furthermore, it is worth pointing out that - considering, for example, the symptoms of "civilising" of human societies proposed by the German sociologist and cultural philosopher Norbert Elias - it can be justifiably doubted whether realising the socio-practical postulates of gender studies would, in fact, constitute a civilizational step forward for humanity. In the light of Elias' understanding of the symptoms of humanity "civilising" itself, the socio-practical postulates of gender studies should be regarded as demands whose implementation would lead rather to "barbarisation" than increased "civilising" of particular societies (cf. Kieliszek, 2014b).

Sixth, gender studies introduce confusion in the senses and meanings of the employed terms, meaning that they use terms such as womanhood, manhood or family in vague and ambiguous ways. What this means is that either meanings drawn from other cultures (languages) are transferred to the senses of such terms, or those senses are broadened in a logically fallacious way. This is done, for example, by indicating that in Japanese culture "womanhood" means something completely different than in American, German or Polish culture and therefore its meaning in American, German, or Polish culture (language) should also be understood differently.

\section{Summary}

Looking at gender studies from the perspective of Bocheński's concept of philosophical superstition, especially considering the observation that given convictions, theories and beliefs should be regarded as philosophically superstitious once they fall under any of the criteria formulated by the Polish philosopher, one can say that gender studies only create a semblance of rationality (truth). In fact, gender studies violate not one, but all six criteria which - as Bocheński indicates - precisely differentiate convictions, theories and beliefs which are irrational from those which are not philosophically superstitious. This allows one to hold justifiable doubt regarding the rationality (truth) of the theses formulated within gender studies and the legitimacy of their socio-practical postulates.

Open Access This article is licensed under a Creative Commons Attribution 4.0 International License, which permits use, sharing, adaptation, distribution and reproduction in any medium or format, as long as you give appropriate credit to the original author(s) and the source, provide a link to the Creative Commons licence, and indicate if changes were made. The images or other third party material in this article are included in the article's Creative Commons licence, unless indicated otherwise in a credit line to the material. If material is not included in the article's Creative Commons licence and your intended use is not permitted by statutory regulation or exceeds the permitted use, you will need to obtain permission directly from the copyright holder. To view a copy of this licence, visit http://creativecommons.org/licen ses/by/4.0/. 


\section{References}

Allison, A. (2007). Japońskie matki i „obentō”: pudełko z drugim śniadaniem jako ideologiczny aparat państwa. In R. E. Hryciuk \& A. Kościańska (Eds.), Gender” perspektywa antropologiczna, vol. 1: Organizacja społeczna. (pp. 146-170). University of Warsaw Press.

Baer, M. (2004). Pułapki tożsamości: kilka uwag o kategoriach płci w narracjach gender studies. ER(R)GO. Teoria-Literatura-Kultura, 2(9), 119-132.

Bartky, L. S. (2007). Foucault, kobiecość i unowocześnienie władzy patriarchalnej. In R. E. Hryciuk \& A. Kościańska (Eds.), Gender” perspektywa antropologiczna, vol. 2: Kobiecość, męskość, seksualność. (pp. 50-75). University of Warsaw Press.

Bocheński, J. (1994). Sto zabobonów. PHILED Publishing Kraków.

Brenner, S. A. (2007). Dlaczego kobiety rządzą w domu: nowe spojrzenie na jawajskie ideologie płci kulturowej. In R. E. Hryciuk \& A. Kościańska (Eds.), Gender” perspektywa antropologiczna, vol. 1: Organizacja spoteczna. (pp. 276-308). University of Warsaw Press.

Channa, S. M. (2007). Hinduska kobieta: konstrukt i prawda w dobie globalizacji. In R. E. Hryciuk \& A. Kościańska (Eds.), „Gender” perspektywa antropologiczna, vol. 1: Organizacja społeczna. (pp. 258-275). University of Warsaw Press.

Chmura-Rutkowska, I., Duda, M., Mazurek, M., \& Sołtysiak-Łuczak, A. (2016). Gender w podręcznikach. Fundacja Feminoteka Warszawa.

Collier, J. F., Rosaldo, M. Z., \& Yanagisako, S. (2007). Czy rodzina istnieje? Nowe ujęcia antropologiczne. In R. E. Hryciuk \& A. Kościańska (Eds.), Gender” perspektywa antropologiczna, vol. 1: Organizacja społeczna. (pp. 60-75). University of Warsaw Press.

Czupryński, W. (2019). Wychowanie w rodzinie w zderzeniu z ideologią gender. Studia Etckie, 21(4), 455-469.

Duda, M. (2016). Dogmat ptci: Polska wojna z gender. Wydawnictwo Naukowe Katedra Gdańsk

Goddard, V. A. (2007). Dziewica i państwo". Płeć i polityka w Argentynie. In R. E. Hryciuk \& A. Kościańska (Eds.), Gender perspektywa antropologiczna, vol. 1: Organizacja społeczna. (pp. 121-145). University of Warsaw Press.

Górecki, P. (2017). Z marginesów do centrum: „Encyklopedia gender” i inne nowe omówienia a przemieszczanie dyscypliny ,gender studies”. Teksty drugie: Teoria literatury, krytyka, interpretacja, 1, 128-138

Graff, A. (2013). Gender i polityka, ale ta prawdziwa. http://www.krytykapolityczna.pl/artykuly/ opinie/20131219/graff-gender-i-polityka-ale-ta-prawdziwa (accessed: 23.02.2021).

Hoodfar, H. (2007). Zasłona w ich umysłach i na naszych głowach: muzułmanki i praktyki zasłaniania. In R. E. Hryciuk \& A. Kościańska (Eds.), Gender perspektywa antropologiczna, vol. 1: Organizacja spoteczna. (pp. 227-257). University of Warsaw Press.

Hryciuk, R. E., \& Kościańska, A. (2007). Wstęp. In R. E. Hryciuk \& A. Kościańska (Eds.), Gender perspektywa antropologiczna, vol. 1: Organizacja społeczna. (pp. 7-17). University of Warsaw Press.

Hummel, R. (1997). Zabobon. In F. König \& H. Waldenfels (Eds.), Leksykon religii. (p. 537). Verbinum Warszawa.

Jacko, J. F. (2013). O naturze filozoficznego zabobonu według Innocentego Józefa Marii Bocheńskiego. Filo-Sofija, 21(2), 135-150.

Jucewicz, A., \& Machinek, M. (2009). Idea gender jako wyzwanie dla teologii. Hosianum Olsztyn.

Kieliszek, Z. (2014a). Próba umiejscowienia ,gender studies” w ramach fundamentalnych metafizyczno-teoriopoznawczych nastawień do rzeczywistości. Kilka wskazówek dla krytyków „gender studies". Studia Warmińskie, 51, 163-181.

Kieliszek, Z. (2014b). Społeczno-praktyczne postulaty stawiane w ramach ,gender studies” - ,cywilizowanie się” czy ,barbaryzacja” społeczeństwa? Próba oceny postulatów genderowych z perspektywy Norberta Eliasa wizji rozwoju cywilizacji. In L. Świto \& M. Tomkiewicz (Eds.), Favor matrimonii"? Teoria i praktyka. (pp. 165-182). Faculty of Theology UWM Olsztyn.

Kołakowski, L. (2009). O zabobonach. In L. Kołakowski, Miniwykłady o maxi sprawach: Trzy serie. (pp. 128-136). Wydawnictwo Znak Kraków.

Kuby, G. (2007). Rewolucja genderowa: Nowa ideologia seksualności. Homo Dei Kraków.

Kuby, G. (2013). Globalna rewolucja seksualna: Likwidacja wolności w imię wolności. Homo Dei Kraków.

Llewelyn-Davies, M. (2007). Kobiety, wojownicy i patriarchowie. In R. E. Hryciuk \& A. Kościańska (Eds.), „Gender” perspektywa antropologiczna, vol. 1: Organizacja społeczna. (pp. 192-224). University of Warsaw Press. 
Martin, E. (2007). Jajo i plemnik. Naukowy romans. In R. E. Hryciuk \& A. Kościańska (Eds.), „Gender” perspektywa antropologiczna, vol. 2: Kobiecość, męskość, seksualność. (pp. 33-49). University of Warsaw Press.

Morris, M. W., Leung, K., Ames, D., \& Lickel, B. (1999). Views from Inside and Outside: Integrating Emic and Etic Insights about Culture and Justice Judgment. Academy of Management Review, 24(4), 781-796.

Niewińska, A. (2014). Raport o gender w Polsce. Fronda Warszawa.

Nisbet, R. (1998). Przesady. Stownik filozoficzny. Fundacja Aletheia Warszawa.

Okley, J. (2007). Uprzywilejowane, wyćwiczone i ułożone. Szkoły z internatem dla dziewcząt. In R. E. Hryciuk \& A. Kościańska (Eds.), Gender perspektywa antropologiczna, vol. 2: Kobiecość, męskość, seksualność. (pp. 76-107). University of Warsaw Press.

Pawłowicz, J. J. (2012). Ideologia „gender” realnym zagrożeniem dla małżeństwa i rodziny. Teologia $i$ Moralność, 11, 139-154.

Podzielny, J. (2016). Gender als Herausforderung für Anthropologie, Politik und Familie laut ausgewählter polnischer Moraltheologen. Family Forum, 6, 189-201.

Rogowski, W. (2013). Ideologia gender w krytyce medialnej środowisk prawicy w Polsce. Świat Idei $i$ Polityki, 12, 26-41.

Rogowski, W. (2015). Ideologia ,gender” w obliczu krytyki Kościoła katolickiego w Polsce. In A. Kusztal \& S. Czapik (Eds.), Religia i Kościoły w polskiej przestrzeni publicznej. (pp. 195-212). University of Opole Press.

Šimo, H. (2019). J.M. Bocheńskiego zabobon filozoficzny a myślenie etyczne. Etyka, 58/2, 71-85. https:// doi.org/10.14394/etyka.955

Stownik jezyka polskiego PWN (2021). Entry: Zabobon, https://sjp.pwn.pl/slowniki/zabobon [2021-03-22].

Sultana, A. M., \& Lazim, A. S. B. (2011). Gender Studies in Teacher Education: An Empirical Research. Asian Social Science, 7(12), 168-174. https://doi.org/10.5539/ass.v7n12p168

Śmieja, W. (2017). Antygenderowe perpetuum mobile. Teksty drugie - Teoria literatury, krytyka, interpretacja, 4, 159-165.

Vance, C. S. (2007). Konstruktywizm społeczny. Kłopoty z historią seksualności. In R. E. Hryciuk \& A. Kościańska (Eds.), Gender perspektywa antropologiczna, vol. 2: Kobiecość, męskość, seksualność. (pp. 15-32). University of Warsaw Press.

Vorgrimler, H. (2005). Zabobon. In H. Vorgrimler, Nowy leksykon teologiczny: Wiara, Objawienie, Dogmat. (p. 436). Verbinum Warszawa.

Werbner, P. (2007). Upolitycznione macierzyństwo i feminizacja obywatelstwa: ruchy kobiece i transformacja sfery publicznej. In R. E. Hryciuk \& A. Kościańska (Eds.), Gender perspektywa antropologiczna, vol. 1: Organizacja spoteczna. (pp. 93-120). University of Warsaw Press.

Whitehead, H. (2007). Łuk i nosidełko. Nowe spojrzenie na zinstytucjonalizowany homoseksualizm wśród Indian Ameryki Północnej. In R. E. Hryciuk \& A. Kościańska (Eds.), Gender perspektywa antropologiczna, vol. 2: Kobiecość, męskośc, seksualność. (pp. 195-238). University of Warsaw Press.

Woodward, K., \& Woodward, S. (2015). Gender studies and interdisciplinarity. Palgrave. Communications, 1(15018), 1-5. https://doi.org/10.1057/palcomms.2015.18

Yanagisako, S. J., \& Collier, J. F. (2007). O ujednoliconą analizę płci kulturowej i pokrewieństwa. In R. E. Hryciuk \& A. Kościańska (Eds.), Gender perspektywa antropologiczna, vol. 1: Organizacja spoteczna. (pp. 21-59). University of Warsaw Press.

Zalewska, P. (2014). Wartości małżeńskie i ich znaczenie w teorii gender. Family Forum, 4, 89-106.

Publisher's Note Springer Nature remains neutral with regard to jurisdictional claims in published maps and institutional affiliations. 


\section{Authors and Affiliations}

\section{Zdzisław Kieliszek $^{1}$ (D}

$\triangle$ Zdzisław Kieliszek

zdzislaw.kieliszek@uwm.edu.pl

1 Department of Philosophy and Canon Law Faculty of Theology, University of Warmia and Mazury in Olsztyn, ul. Hozjusza 15, 11-041 Olsztyn, Poland 